\title{
INTERFERENSI MORFOLOGIS PUISI RUBĀ’I HAMZAH FANSURI
}

\author{
Ihsanudin \\ Forum Arabic Language Focus (ALIF) Yogyakarta \\ zanudinbsa@gmail.com \\ Aimmatul Muslimah \\ Forum Arabic Language Focus (ALIF) Yogyakarta \\ aime.heaven@yahoo.com
}

\begin{abstract}
Abstrak
Interferensi dapat terjadi ketika seseorang menggunakan dua bahasa atau lebih, dan terjadi kontak bahasa. Lazimnya terjadi di bahasa lisan dan tulisan. Salah satu penggunaan bahasa tulis adalah puisi Rubā'i karya Hamzah Fansuri. Ia dapat dikatakan seorang individu yang dapat memakai dua bahasa atau lebih di tengah masyarakat dan terjadi kontak bahasa sehingga terjadi interferensi bahasa. Lebih tepatnya terjadi permasalahan interferensi morfologis. Objek penelitian ini adalah kata-kata yang mengalami interferensi secara morfologis, tipe penelitian ini, kajian pustaka dan deskriptif-kualitatif. Teknik padan translasional digunakan untuk menganalisis data. Permasalahan yang ingin dijawab (1) bentuk-bentuk interferensi morfologis, dan (2) sebabsebab terjadinya interferensi bahasa. Hasil yang diperoleh dari penelitian ini. Pertama, terdapat 241 kata yang mengalami interferensi secara morfologis. Bentuk-bentuk interferensi berupa afiksasi dan bentuk kata gandaan (majemuk). Afiksasi yang terjadi berupa imbuhan prefik (awalan), sufik (akhiran), dan konfik (awalan dan akhiran). Kedua, terdapat dua sebab utama terjadinya interferensi, yaitu faktor linguistik (kebahasaan) dan faktor non linguistik (non kebahasaan). Faktor linguistik, diantaranya: tidak ada padanan kata dalam bahasa Melayu, terbawanya bahasa ibu, kosakata Arab ringkas kata luas makna. Faktor nonlinguistik, diantaranya: Hamzah Fansuri seorang multilingual, Hamzah Fansuri seorang sufi, pengaruh Islamisasi di Nusantara, puisi sebagai budaya kesusastraan awal Islam di Nusantara, berkembangnya tulisan Jawi (Melayu-Arab).
\end{abstract}

Kata kunci: Interferensi, Rubā'i, Proses Morfologis. 


\begin{abstract}
Interference is used to two languages or more by person and happened language contact, usually in speaking and writing. Ruba' ' $i$ of Hamzah Fansuri it is example interference in writing. Hamzah Fansuri is individual in his community whom used to two language or more and impact this phenomena it's call by interference language. Thats exactly, problem morphological interference. This objec research is interference words in Rubā' $i$, type research is library research and descriptive-qualitative. Translational tecniques used for analysis data. The purpose study to describe (1) forms morphological interference in Ruba' 'i poems, (2) interference factors in Ruba' 'i poems. Results this research. The first, 241 words has morphological interference. Interference forms of affixation and the form of multiple word. Affixation is form of prefixs, suffixs, and confixs. The secondly, language interference has two factors: linguistic and non linguistic. In linguistic factors, Malay doesnt have synonim word in arabic, his poems also affected by his first language, Arabic word has little forms but more means. As for non linguistic factors are: Hamzah Fansuri is multilingual, he is a sufi, factor influence of Islamization in Nusantara, poetry as an early literary culture of Islam in Nusantara, the development of Jawi (Malay-Arabic).
\end{abstract}

Keywords: Interference, Rubā i, Morphological process.

\title{
A. Pendahuluan
}

Setiap bahasa yang bertemu dengan bahasa lain pasti terjadi kontak. Banyak faktor yang mempengaruhi penggunaan bahasa pertama (BI) dan bahasa kedua (B2), salah satunya adalah karena persinggungan dua bahasa, atau disebut dengan kontak bahasa. ${ }^{1}$ Transfer bahasa atau interferensi sebagai akibat terjadinya kontak bahasa sering dipandang sebagai fenomena yang wajar dan positif. Hal ini terjadi karena pemindahan unsur-unsur bahasa satu dengan yang lain, atau sebaliknya disadari oleh pemakai bahasa. ${ }^{2}$ Secara

${ }^{1}$ Kontak bahasa dapat terjadi secara langsung maupun tidak langsung. Menurut Sarah G. Thomson, kontak bahasa secara langsung terjadi karena masuknya bahasa sumber dalam bentuk (hanya morfem, morfem dengan struktur, atau hanya struktur) dengan atau tanpa perubahan dari bahasa sumber yang menandai dalam suatu proses. Kedua, kontak bahasa tak langsung memiliki arti efek/ dampak penggunaan tak langsung dari kontak bahasa yang mana ada kecenderungan penggunaan dua bahasa. Lihat Sarah G. Thomason, Language Contact, (Edinburgh: Edinburgh University Press Ltd, 2001), h. 62.

2 Pranowo, Analisis Pengajaran Bahasa Untuk Mahasiswa Jurusan Bahasa dan Guru Bahasa, (Yogyakarta: Gadjah Mada University Press, 1996), h. 7. 
langsung maupun tidak langsung proses terjadinya interferensi terjadi pada bahasa lisan dan tulis. Kemampuan penutur dwibahasa atau multilingual yang dapat ia kuasai secara lisan biasanya terjadi secara spontan dan reflek. Sebaliknya, bahasa tulis yang digunakan penutur dimungkinkan banyak benarnya, karena masih dapat diedit oleh penutur/ penulis. Namun jika masih terdapat kesalahan, hal tersebut akan terjadi interferensi antara sistem bahasa B1 dan B2. Artinya penutur belum menguasai B2 secara baik. Meski demikian ia tetap dianggap sebagai kedwibahasaan menurut beberapa linguis seperti MacKey, Hartman, Stork, dan Haugen. ${ }^{3}$

Proses interferensi bahasa dapat sejalan dengan proses terjadinya difusi kebudayaan dalam ilmu sosiologi. Gejala interferensi dapat dilihat dalam tiga dimensi kejadian. Pertama, dimensi tingkah laku berbahasa dari individu di tengah masyarakat. Kedua, dimensi sistem bahasa dikenal dengan sebutan interferensi sistemik, yaitu pungutan bahasa. Ketiga, dimensi pembelajaran bahasa dikenal dengan sebutan interferensi pendidikan. ${ }^{4}$ Terjadinya interferensi tersebut memberikan dampak positif dan negatif. Dari sisi positif menurut Abdul Chaer merupakan langkah awal untuk menyerap kosakata lain agar terintegrasi ke dalam B1, dalam arti lain menjadi kata serapan. ${ }^{5}$ Dari sisi negatifnya, interferensi merupakan gejala yang dapat merusak sistem bahasa atau tatabahasa karena dapat menimbulkan "pengacauan" atau "kekacauan" menurut Nababan (1984), bahkan Hartman dan Stork (1972) menyebutnya dengan "kekeliruan", akibat terbawanya kebiasaan-kebiasaan ujaran bahasa ibu atau dialek ke dalam bahasa atau dialek kedua. ${ }^{6}$ Terlepas dari dampak adanya positif dan negatif adanya interferensi pada suatu tuturan, namun interferensi yang terjadi pada suatu masyarakat

\footnotetext{
${ }^{3}$ Ibid., h. 8 .

${ }^{4}$ Paul Ohoiwutun, Sosiolinguistik: Memahami Bahasa dalam Konteks Masyarakat dan Kebudayaan, (Jakarta: Visipro, 2002), h. 72-74.

${ }^{5}$ Interferensi dalam bidang leksikal (kosakata) mempunyai nilai positif yang besar untuk pengembangan suatu bahasa. Hockett (1958) menyatakan bahwa interferensi merupakan suatu gejala terbesar, terpenting, dan paling dominan dalam bahasa. Dalam fonologi misalnya, sebelum adanya EYD (1972), bunyi /f/ dan bunyi / $\mathrm{x} /$ yang berasal dari bahasa asing belum diakui sebagai fonem bahasa Indonesia. Karena terdapat pasangan-pasangan seperti kata kapan X kafan, khas X kas. Pada tataran leksikal dan semantik, seperti kata research menjadi riset, system menjadi sistem, zuursak menjadi sirsak, air port menjadi bandar udara, network menjadi jaringan, dll. Baca lebih lengkap dalam Abdul Chaer dan Leonie Agustina, Sosiolinguistik Perkenalan Awal, (Jakarta: Rineka Cipta, 2001), h. 126-131.

${ }^{6}$ Ibid., h. 121.
} 
terbuka merupakan suatu fenomena bahasa yang perlu diteliti lebih mendalam. Adapun interferensi ini terjadi pada subsistem fonologi, morfologi, sintaksis, serta serpihan-serpihan kata, frasa, dan klausa di dalam suatu kalimat. ${ }^{7}$

Dalam penelitian ini akan menguraikan interferensi pada subsistem morfologi. Hal ini dilakukan mengingat banyak terjadi interferensi BI ke dalam B2 dalam bait puisi Rubā' $i^{8}$ karya Hamzah Fansuri. Sebagaimana contoh di bawah ini:

"Ukhrujkan dirimu dari pada sayyi'āt

jangan taqsir mengerjakan hasanāt

Tuntut olehmu hakikat șalāt

Supaya wasil adamu dengan Dhāt"'

Kata "Ukhrujkan" di atas mengalami interferensi secara morfologis, yaitu masuknya B1 (bahasa Melayu), morfem sufik ${ }^{10}$ kan terhadap B2 (bahasa Arab), "Ukhruj". Secara kuantitas kosakata Arab dalam puisi Rubā'i karya Hamzah Fansuri ada pada setiap bait. Sehingga penelitian ini perlu dilakukan secara detail untuk mengetahui bentuk apa saja kata yang mengalami interferensi dan sebab-sebabnya.

\section{B. Mengenal sosok Hamzah Fansuri}

Hamzah Fansuri hidup di abad ke-16 dan akhir abad ke-17. Ia seorang ahli tasawuf. Dari tempat lahirnya, Barus mengembara ke Pahang, Banten, Kudus, pernah mengunjungi Mekah, Madinah, dan Siam (daerah dekat Thailand). Ia hidup sebagai seorang fakir (sebutan

\footnotetext{
${ }^{7}$ Ibid., h. 124.
}

${ }^{8}$ Naskah berjudul "Rubā' $i$ " atau "Rubā'i Hamzah Fansuri" adalah karya Syaikh Hamzah Fansuri, sedangkan naskah berjudul "Syarah Rubāi" atau "Syarah Rubā'i Hamzah Fansuri" adalah karya Syaikh Syamsuddin As-Samatrani atau AsSamatrā'ī'. Sementara itu, judul teks $R u b \bar{a}$ 'i di dalam naskah tidak ada. Pemberian judul teks Rubāi diberikan oleh Syaikh Syamsuddin As-Samatrā'̄i dalam karyanya yang berjudul "Syarah Rubā' $i$ " dengan mengambil baris pertama pada bait pertama. Selanjutnya oleh Sangidu memberikan judul pertama dari judul utama teks $R u b \bar{a}$ ' $i$ sebagaimana telah dilakukan oleh Syaikh Syamsuddin As-Samatrā'̄̄. Lihat: Sangidu, Naskah-naskah Melayu Karya Hamzah Fansuri: Kajian Filologis, (Yogyakarta: Unit Penerbitan Sastra Arab, Fakultas Ilmu Budaya, 2004), h. 118. Dalam penelitian ini menggunakan buku yang dikarang oleh G.W.J Drewes dan L.F. Brake, The Poems of Hamzah Fansuri, (Leiden: Foris Publications, 1986).

${ }^{9}$ G.W.J Drewes dan L.F. Brake, The Poems of Hamzah Fansuri, (Leiden: Foris Publications, 1986), h. 42.

${ }^{10}$ Sufik adalah imbuhan morfem pada akhir kata dasar. 
salah satu maqam dalam ilmu tasawuf). Karya-karyanya sangat berpengaruh, lebih-lebih berkat usaha muridnya Syamsuddin dari Pasai, juga sangat berpengaruh di kalangan para wali di Pulau Jawa. ${ }^{11}$

Abdul Hadi dalam sebuah artikelnya Hamzah Fansuri Penyair Aceh menyatakan dalam sajak-sajak Hamzah Fansuri, ia telah mengembara ke berbagai tempat dan negeri seperti Jawa, Siam, Semenanjung Melayu, Pesisir Sumatra, Persia dan tanah Arab. Dalam hal kebahasaan, Hamzah Fansuri selain menguasai bahasa Ibu (bahasa Melayu), ia juga mahir pula dalam bahasa-bahasa Persia dan Arab. Penguasaan bahasa inilah yang membuat ia sangat mudah memahami berbagai buku tasawuf dari sufi-sufi terkemuka Persia. Di dalam uraian-uraian tasawufnya misalnya tak sedikit sajak-sajak para sufi Persia itu ia kutip dalam bahasa aslinya, kemudian dibubuhi terjemahannya dalam bahasa Melayu. ${ }^{12}$

Pengalaman Hamzah Fansuri sebagai seorang sufi dan menciptakan karya-karyanya dalam bentuk sajak-sajak puisi telah membuktikan bahwa ia juga seorang penyair yang ulung. Pengalaman realita kehidupan dan kerohaniannya telah memadukan aspek jasmani dan rohaninya membentuk karya yang luar biasa. Penguasaan ilmu tasawuf yang ia peroleh dengan bakat yang dimilikinya dapat menggambarkan bahwa dirinya telah memadukan tahapan pengalaman kerohanian yang ia capai dengan tempat di mana ia mencapainya. Artinya ia dapat mengkombinasikan antara dunia luar dan dunia dalam yang sangat inti dalam penulisan puisi, menjadi suatu ungkapan yang utuh, berdimensi ganda, dan menyaran ke banyak segi. ${ }^{13}$

Hamzah Fansuri mempelajari ilmu tasawuf di Baghdad. Ajaran tasawuf yang ia peroleh adalah ajaran Syekh Abdul Qadir Jailani. ${ }^{14}$ Namun jika ditelisik dari karya-karyanya, Hamzah Fansuri sendiri tidak menunjukkan bahwa bukan pengaruh yang Syekh Jailani yang paling besar kepadanya, melainkan ajaran Ibn Arabi. Disamping itu ia telah dekat dengan ajaran tasawuf dari karya tokoh-tokoh sufi, seperti

${ }^{11}$ Ensiklopedi Indonesia, (Jakarta: 1980)

${ }^{12}$ Penyuting Abdul Hadi W.M, dan L.K. Ara, Hamzah Fansuri Penyair Sufi Aceh (Lotkala: 1984), h. 14.

${ }^{13}$ Abdul Hadi W.M, dan L.K. Ara, Hamzah Fansuri ..., h. 14.

${ }^{14}$ Dinyatakan dalam bait penutup ikatan-ikatan Syair I (MS Jak. Mal. 83):

Hamzah Fansuri nin 'ilmunya zhahir

Ustadhnya Sayyid 'Abd al-Qadir

Mahbubnya terlalu hadir

Dengan dirinya nantiasa satir 
Bistami, Baghdadi, Al-Hallaj, Imam Ghazali, Mas'udi, Farid Attar, Jalaluddin Rumi, Shabistari, Maghribi, Iraqi, Sa'di, Nikmatullah, Jami' dan Karim Al-Jili. ${ }^{15}$

Hamzah Fansuri wafat di Singkil, dekat kota kecil Rundeng. Dapat diperkirakan ia wafat pada masa awal atau akhir masa pemerintahan Sultan Iskandar Muda Meukuta Alam (w. 29 Rajab 1046 H/ 27 Desember 1636 M). Dimakamkan di gampong (desa) Oboh kecamatan Rundeng di Hulu Sungai Simpang Kiri, Aceh Singkil. Menurut cerita yang berkembang dalam masyarakat Singkil. Semasa hidup Hamzah Fansuri ia pernah berwasiat bahwa ia kelak akan kembali dan dimakamkan di Desa Oboh ini. Dalam cerita itu disebutkan, dulu sebelum Hamzah Fansuri pergi merantau meninggalkan desa Oboh, ia menanam satu bambu bibit padi hingga tumbuh dan panen. Lalu waktu ditakar ia dapatkan hasil panen sama persis dengan satu bambu bibit yang dulu ia tanam, artinya tidak lebih dan tidak kurang. Lalu, Hamzah Fansuri berkata kepada masyarakat setempat, "lihatlah, tanah ini tidak pernah berbohong dan di tempat ini kelak apabila saya meninggal akan kalian kuburkan, di tanah yang tak berbohong ini". ${ }^{16}$ Adapun karya-karya Hamzah Fansuri dari segi pemikirannya banyak dipengaruhi oleh Ibn Arabi, dibanding dengan gurunya Syeikh Abdul Qadir Jailani. Ia berkarya dalam bahasa Melayu untuk pembaca yang tidak mengerti bahasa Arab dan Persia.

Karya Hamzah Fansuri mula-mula diedit oleh Doorenbos tahun 1933. ${ }^{17}$ Karya prosa Hamzah Fansuri yang terpenting ialah (1) Asrar al-Arifin fi Bayani Ilmis-Suluk wat-Tauhid (Rahasia Ahli Ma'rifat; kitab ini membahas masalah ilmu tauhid dan ilum tarekat; dalam kitab ini tersimpan ajarannya), (2) Syarābul Asyiqin (Minuman Orang Berahi; kitab ini membicarakan masalah tarekat, syariat, hakikat, dan makrifat), (3) Zinat al-Muwahidin (Perhiasan Ahli Tauhid), (4) AlMuntahi (kitab ini membicarakan masalah tasawuf), dan (5) Ruba'i Hamzah Fansuri (syair sufi, yang penuh butir-butir filsafat). Karya yang terakhir ini meski berupa prosa namun pada kenyataannya seperti bait puisi yang dinarasikan, secara mayoritas bersajak a-a-a-a. Karyanya yang berupa syair, antara lain, (1) "Syair si Burung Pingai",

${ }^{15}$ Abdul Hadi W.M, dan L.K. Ara, Hamzah Fansuri ..., h. 16.

16 Muliadi Kurdi, Hamzah Fansuri: Ulama Aceh Terkenal Dalam Kealiman dan Kesufian, (Aceh: Lembaga Naskah Aceh "NASA", 2013), h. 51.

17 J. Doorenbos, De geschriften van Hamzah Fansuri, Leiden, 1933 dalam Claude Guillot dan Ludvik Kalus, Batu Nisan Hamzah Fansuri, terj. Rita Parasman, (Jakarta: Ecole Francaise d'Extreme-Orient dan Departemen Kebudayaan dan Pariwisata, 2007), h. 11. 
(2) "Syair Si Burung Pungguk", (3) "Syair Sidang Fakir", (4) "Syair Dagang", dan (5) "Syair Perahu". ${ }^{18}$

\section{Bentuk-bentuk Interferensi Morfologis}

Bentuk interferensi morfologis yang dimaksud dalam pembahasan ini adalah penggunaan bentuk imbuhan (afiks) dalam morfem bahasa Melayu yang melekat pada kata Arab di dalam bait puisi Rubā'i karya Hamzah Fansuri. Setelah melakukan penelitian, terdapat beberapa imbuhan morfem bahasa Melayu, diantaranya: prefik (awalan), sufiks (akhiran), konfiks (awalan dan akhiran), dan kata gandaan (majemuk). Ditemukan 241 kata yang mengalami afiks di dalam 192 bait. Di bawah ini bentuk-bentuk kata yang mengalami afiksasi. ${ }^{19}$

\section{Prefiks}

Prefik merupakan imbuhan yang diletakkan di awal perkataan kata dasar. Peneliti menemukan 44 bait yang di dalamnya terdapat 48 kata, terdiri dari prefik ber-, ter-, kau-, dan ke-. Berikut rinciannya: 20 kata berprefik ber-, diantaranya: berwaqtu, berwaqtu, bermithāl, bermithāl, bermakām, berșifat, berjihat, bermakān, bersyāhil, bersyāhil, berḥāil, berḥāil, bermakān, bermakān, bermakān, bermanfa'at, bersyuhbat, bernasyīb, bersyuhbat, bermu'allim. Terdapat dua kata berprefik ter-, yaitu: terțila dan ter 'ādat. Terdapat 25 kata berprefik kau-, diantaranya: kaughäfil, kautaghā, kautawbat, kausākin, kau-ghāfil, kaurākib, kauwāsyil, kaughāfïl, kaujālis, kaulābis, kaulābis, kauzāhir, kaughāail, kaujālis, kaulābis, kausyā'im, kauqā'im, kau'ārif, kaughāfil, kaughāfìl, kaughāfil, kaurādlī, kau'āshiqūn, kauqā'im, kausahwa. Ada satu kata yang berprefik ke-, yaitu ke-marghūb al-qulüb.

2. Sufiks

Sufik merupakan imbuhan yang terletak di akhir kata dasar. Setelah melakukan penelitian terhadap puisi $R u b \bar{a} i$ karya Hamzah Fansuri, terdapat enam imbuhan akhiran (sufik), diantaranya: bentuk imbuhan sufik -mu, -kan, -lah, -pun, -i, dan -nya. Terdapat 136 bait yang didalamnya terdapat imbuhan sufiks, berikut perinciannya: sufik -mu 34 bait terdapat 42 kata, diantaranya: 'āshiqmu, maḥbūbmu,

${ }^{18}$ Edwar Djamaris dan Saksono Prijanto, Hamzah Fansuri dan Nuruddin Ar-Raniri, (Jakarta: Proyek Pengembangan Kebudayaan Direktorat Jendral Kebudayaan, 1996), h. 3-4.

\footnotetext{
${ }^{19}$ Afiksasi adalah suatu proses penambahan imbuhan pada kata dasar.
} 
i ‘tiqādmu, sharì'atmu, țarīqatmu, haqūqatmu, ma 'rifatmu, tawhīdmu, 'uтитти, tawakkulmu, ma'syiyatmu, maḩbūbmu, mahbūbmu, mạ̣būbmu, jawharmu, maḥbūbmu, tawhidmu, 'ishqimu, maḥbūbmu,

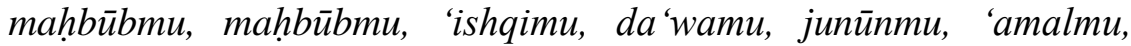
maḥbūbmu, mạ̣būbmu, mạ̣būbmu, markabmu, markabmu, 'ishqimu, bātịmu, mushāhadahmu, fi 'ilmu, fi 'ilmu, 'aqalmu, ilmumu, suluhmu, 'amalmu, ghazāmu, markabmu, wāsyilmu.

Ada 10 bait sufik -kan dan terkandung 10 kata, diantaranya: napikan, ukhrujkan, faraqkan, wāhidkan, hafazkan, ukhrujkan, wāhidkan, ithbātkan, takhsȳ̄sykan, khabarkan. Ditemukan dua kata yang sama bersufik -lah, yaitu; wāsyillah dan wāsyillah. Adapun yang bersufik - pun terdapat dua kata, yaitu: sharī'atpun dan hajjpun. Kata bersufik -kau hanya ditemukan satu kata, yaitu: khidmatkau, dan kata bersufik - $i$ terdapat enam kata, diantaranya: insāni, insānī, rūḥānī, sulțāni, fansūri, arabi.

Terdapat 83 bait yang di dalamnya terdapat 120 kata bersufik nya, yaitu: sharī'atnya, sharī'atnya, țarīqatnya, haqīqatnya, márifatnya, dhātnya, zuhūrnya, ma'nanya, syamadnya, ma'nanya, awwalnya, qudratnya, haqīqatnya, 'ilmunya, șifätnya, ațarnya, țawfānnya, shuiūnnya, hukumnya, haqiqatnya, wāsyilnya, muhịtnya, ma'nanya, hakikatnya, haqiqatnya, ma'nanya, ma'nanya, żāhirnya, jazānya, wāsyilnya, ilmunya, kunhinya, kunhinya, manzilnya, da'wanya, ma'nanya, syifatnya, amalnya, da'wānya, kunhinya, haqīqatnya, adhābnya, lisānnya, ākhirnya, żāhirnya, asmānya, asmānya, bāṭinnya, zāhirnya, 'āshiqnya, rūhinya, nabinya, burhānnya, qur'ānnya, furqānnya, subḥānnya, millatnya, żāhirnya, aqwālnya, af'ālnya, ahwālnya, a'mālnya, sharī'atnya, hikmatnya, ustādhnya, mahbū̄onya, asmanya, șifātnya, 'uzlatnya, asmā'nya, rahmatnya, da'wanya, ma'nanya, wasȳ̄lnya, karamatnya, wāsyilnya, markabnya, awwalnya, millatnya, masyhafnya, șüinya, sharì'atnya, ilmunya, ilmunya, fardlunya, ilmunya, madhhabnya, 'ishqinya, wujudnya, 'ishqinya, maḩūbnya, marghūbnya, mațūbnya, markūbnya, ilmunya, nūrnya, syāfinya, nūrinya, ummatnya, burhānnya, qur'ānnya, furqānnya, qurbānnya, sațarnya, jabbārnya, ghaffārnya, qahhārnya, jabbārnya, șifātnya, awwalnya, wāhidnya, șamadnya, wāsyilnya, awwalnya, akhirnya, bātinnya, asmā'nya, wāsyilnya, wāsyilnya, țawfannya.

\section{Konfiks}

Konfik adalah imbuhan yang mengapit antara kata dasar, terdapat penggabungan imbuhan di awal kata dasar dan akhir kata 
dasar. Terdapat 9 bait yang berkonfiks di- -kan, kau- -kan, me- -kan, berikut penjelasannya. Terdapat 4 kata berkonfik $d i-$-kan, yaitu: dii 'tiqadkan, ditamhīlkan, ditakhsyīskan, ditakhsyīsykan. Ada 1 kata berkonfik kau- -kan, yaitu: kaumuhtājkan, dan terdapat 4 kata berkonfik me--kan, yaitu: kaumuhtājkan, mengislamkan, menapikan, menapikan.

4. Kata Gandaan (majemuk)

Kata gandaan merupakan gabungan dua kata dasar yang sama yang memiliki makna ganda. Terdapat 2 bait yang mengandung kata gandaan (majemuk), yaitu: terdāir -dāir dan terțāir-țāir.

\section{Sebab-sebab Interferensi Morfologis}

Interferensi terjadi karena adanya kontak bahasa, hal ini tidak terlepas dari penutur yang menguasai lebih dari satu bahasa atau lebih (multilingual). Artinya Hamzah Fansuri menggunakan kata Arab dalam puisi Rubā'i merupakan bentuk perilaku berbahasa di tengah masyarakat. Akibat penggunaan kata Arab ini terjadi interferensi secara morfologis. Sebab terjadinya interferensi tersebut tidak terlepas dari dua faktor utama, yaitu faktor linguistik (kebahasaan) dan non linguistik (nonkebahasaan). Di bawah ini peneliti deskripsikan lebih lanjut.

\section{Faktor Linguistik}

Faktor linguistik atau kebahasaan merupakan salah satu faktor seorang penutur melakukan interferensi. Adapun faktor linguistik berkaitan dengan sistem internal bahasa. Terdapat beberapa subsistem linguistik, yaitu fonologi, morfologi, sintaksis, dan leksikal. Keempat subsistem tersebut membangun sistem bahasa dari dalam struktur sistem bahasa itu sendiri. Dalam bait puisi Rubā'i ini peneliti melihat Hamzah Fansuri sangat banyak menggunakan kosakata Arab. Menurut Abdul Hadi tidak kurang 1.200 kata-kata Arab dijumpai dalam 32 ikat-ikatan syair Hamzah Fansuri. ${ }^{20}$ Peneliti menemukan beberapa sebab interferensi bahasa yang dilakukan Hamzah Fansuri dari faktor linguistiknya. Diantaranya: tidak ada padanan kata dalam bahasa Melayu, terbawanya bahasa ibu, kosakata Arab luas makna ringkas kata.

${ }^{20}$ Abdul Hadi, Tasawuf yang Tertindas: Kajian Hermeneutik terhadap Karya-karya Hamzah Fansuri, (Jakarta: Paramadina, 2001), h. 219-227. 


\section{a. Tidak Ada Padanan Kata dalam bahasa Melayu}

Bahasa Arab yang digunakan Hamzah Fansuri di dalam bahasa tulisnya, tidak terlepas dari jati diri penulis itu sendiri. Al-Attas menyebutkan bahwa Hamzah Fansuri ahli di bidang tasawuf. Hal ini menandakan bahwa selain seorang intelektual di masanya, Hamzah Fansuri juga terpandang sebagai seorang sufi. Beberapa karya dilahirkan darinya, dan tidak jarang ungkapan tasawuf berbahasa Arab terdapat di dalam karyanya, terlebih di dalam bait puisi Rubā' $i$ nya. Ungkapan-ungkapan Arab tersebut dinukilkan dari ayat alQur'an, al-Hadits, pepatah, ucapan sahabat, dan penyair sufi lainnya.

Bahasa Arab memiliki kekhusan tertentu baik aspek lahir seperti yang telah di sebutkan di atas, dan aspek batin, memiliki makna spritual dan sirr tertentu. Secara kuantitas penggunaan kata Arab telah memenuhi di dalam bait-bait Rubā'i karya Hamzah Fansuri. Oleh sebab itu, penggunaan kata Arab menjadi ciri khas di dalam puisinya dikarenakan tidak adanya kesepadanan di dalam bahasa ibunya, yaitu bahasa Melayu. Bahkan bahasa-bahasa lain di seluruh dunia ini. Inilah sebab sisipan kata Arab lebih mendominasi dibanding dengan bahasa selain bahasa ibunya.

Selain hal di atas, unsur-unsur kata dalam bahasa Melayu sebenarnya merupakan pinjaman dari bahasa Arab. Hal ini terjadi sangat dimungkinkan kebudayaan saat itu sangat erat kaitannya kebudayaan dalam Islam. Istilah Arab yang dipinjam dan masuk pada bahasa Melayu menimbulkan munculnya interferensi secara sistematik. Sebagaimana yang diungkapkan P.W.J. Nababan, mengatakan bahwa mekanisme perubahan kebahasaan dalam interferensi sistematik ialah pungutan (borrowing) yang berhubungan erat dengan pungutan kebudayaan. ${ }^{21}$

\section{b. Terbawanya Bahasa Ibu}

Telah disebutkan sebelumnya bahwa Hamzah Fansuri adalah penutur bahasa Melayu dan dijadikan sebagai bahasa ibunya. Secara naluri manusia berkehidupan sosial pasti melakukan komunikasi dengan manusia lain di lingkungan sekitarnya. Maka ketika seorang penutur bahasa itu pergi dari daerah kampungnya, misalkan, lalu kembali ke daeral asalnya akan terjadi pencampuran antara bahasa ibu dengan bahasa di luar daerahnya. Dominasi bahasa ibu ini dikarenakan sejak lahir ia telah bercengkrama dan berinteraksi dengan bahasa ibunya. Sehingga meskipun ia keluar daerah yang

\footnotetext{
${ }^{21}$ Nababan. P.W.J. Sosiolingustik, (Jakarta: Gramedia, 1984), h. 35.
} 
berbeda bahasanya, dan kembali lagi di tanah kelahirannya akan terjadi perubahan dalam bahasanya. Dengan arti lain, ia lebih menggunakan bahasa di luar daerahnya dengan bercampur tatabahasa ibunya, atau sebaliknya, terdapat kata-kata dari bahasa lain ke dalam bahasa ibunya.

Dari pernyataan di atas, sudah jelas bahwa terbawanya bahasa Melayu sebagai bahasa ibu Hamzah Fansuri merupakan bawaan sejak lahir. Ia lebih dahulu mempelajari dan menguasai bahasa Melayu dengan baik. Bahasa Melayu secara otomatis tertancap pada dirinya, dan memiliki rasa nasionalisme yang tinggi terhadap bahasa Melayu. Apapun yang terjadi ketika ia keluar dari daerah tanah kelahirannya, dan kembali ke daerahnya tetap akan menggunakan bahasa ibunya, meski bercampur dengan bahasa lain, misal: bahasa Arab, bahasa Jawa, dan bahasa Parsi. Inilah yang menyebabkan adanya imbuhan morfem bahasa Melayu dalam kata Arab di dalam bait-bait puisi Rubā'i sehingga terjadi interferensi bahasa secara morfologis.

\section{c. Kosakata Arab Luas Makna Ringkas Kata}

Berbicara tentang bahasa Arab yang menjadi salah satu bahasa di dunia ini tidak terlepas dari makna yang terkandung dalam bahasa Arab itu sendiri. Bahasa Arab selain menjadi bahasa al-Qur'an, kitab pedoman umat Islam, juga telah menjadi bahasa internasional. Mengapa bahasa Arab menjadi salah satu bahasa yang prestise di pencaturan bahasa internasional ?, tidak lain karena bahasa Arab memiliki kekhasan sendiri. Salah satunya bahasa Arab memiliki bentuk tulisan yang pendek namun memiliki arti yang cukup luas. Misalkan kata qi (ق) terbentuk dari imperatif/ fi'l amr / kata perintah, kata itu memiliki arti "bertakwalah". Meskipun terbentuk dari satu huruf, yaitu huruf qaf dalam bahasa Arab sudah termasuk satu kata.

Kata $q i$ di atas menunjukkan bahwa kosakata Arab ringkas katanya namun memiliki makna yang cukup luas. Begitu halnya Hamzah Fansuri menggunakan kata Arab didasarkan pada kosakata Arab lebih prestise dibanding dengan bahasa Melayu. Makna kata yang terkandung dalam kata Melayu belum mencukupi makna yang diinginkan Hamzah Fansuri, lain halnya kata Arab. Misalnya, kata kemarghub 'l-qulüb (menuju tempat yang diinginkan dalam hati-hati).

Dengan demikian, Hamzah Fansuri sebenarnya menggunakan kata Arab dari segi kualitas dan kuantitas. Secara kualitas, telah dikemukakan sebelumnya bahwa keunikan bahasa Arab salah satunya mempunyai bentuk kata ringkas namun makna yang terkandung begitu luas. Dari segi kuantitas, aktualisasi Hamzah Fansuri terhadap 
bahasa Arab telah banyak menggunakan kosakata Arab lebih dari 1200 kata dalam puisi Rubā'inya. Ini menandakan Hamzah Fansuri sangat dekat dengan bahasa Arab dalam aktifitas kesehariannya.

\section{Faktor Non Linguistik}

Faktor non linguistik (non kebahasaan) merupakan penyebab interferensi dari faktor eksternal linguistik. Faktor eksternal linguistik di sini berhubungan erat dengan situasi dan kondisi ditinjau dari sisi budaya, agama, status sosial, ekonomi, politik, dan lain-lain yang melingkupi Hamzah Fansuri.

Hamzah Fansuri sebagai seorang penyair, sufi, budayawan, dan intelektual menandakan bahwa Hamzah Fansuri seorang yang multitalenta. Dalam arti lain, dilihat dari segi kebahasaan baik bahasa lisan maupun tulisan, Hamzah Fansuri telah menguasai beberapa bahasa, yaitu bahasa Melayu, bahasa Arab, bahasa Jawa, dan bahasa Persia. Di bawah ini penyebab Hamzah Fansuri melakukan interferensi bahasa secara morfologis.

\section{a. Hamzah Fansuri Seorang Multilingual}

Dampak yang paling utama terjadinya interferensi bahasa adalah kedwibahasaan penutur atau multilingual. Hasrat untuk mengungkapkan bahasa selain bahasa yang ia kuasai sangat kuat. Karena sifat manusia itu sendiri ada kretif dan dinamis. Perkembangan bahasa sejalan dari dengan kebudayaan suatu bangsa. Maka bahasa dapat berkembang secara dinamis dan secara tidak langsung digunakan oleh masyarakat tutur sesuai zamannya. Dari hal tersebut, sangat mungkin bahasa yang dulunya dianggap paling baik, pada masa sekarang biasa saja.

Sudah tidak diragukan lagi bahwa Hamzah Fansuri seorang multilingual. Penggunaan bahasa Melayu sebagai B1 (bahasa pertama) dan bahasa lain seperti bahasa Arab, bahasa Parsi, bahasa Jawa sebagai B2 (bahasa kedua), B3 (bahasa ketiga), dan B4 (bahasa keempat) memperkuat akan dirinya sebagai penutur multilingual. Penggunaan B1 (bahasa Melayu) oleh Hamzah Fansuri sebagai bahasa ibu dan digunakan untuk berinteraksi dengan orang lain mempunyai dampak atau pengaruh bagi diri Hamzah Fansuri sendiri.

Karena seringnya menggunakan bahasa ibu, bahasa Melayu telah melekat pada diri Hamzah Fansuri. Dapat dilihat dalam menggunakan bahasa tulis struktur bahasa Melayu masuk pada struktur bahasa lain, misalnya banyak ditemukan morfem bahasa Melayu masuk pada struktur bahasa Arab dalam bait-bait Rubā'inya. Kata maḥbubmu merupakan gabungan dua morfem, antara morfem 
sufik $m u$ - dan morfem nomina Arab "مَحْبُوْبُ". Ini merupakan fenomena yang unik, mengambil fragmen struktur terkecil dari bahasa Melayu lalu dimasukkan dalam fragmen bahasa Arab. Maka jadilah satu kosakata yang terbentuk dari dua struktur sistem bahasa. Menggunakan satu kosakata dengan dua struktur sistem bahasa, yakni bahasa Melayu dan bahasa Arab. Hal inilah penyebab dari Hamzah Fansuri melakukan interferensi.

Interferensi bahasa merupakan kesalahan-kesalahan yang terjadi ketika seseorang mempelajari bahasa kedua. Karena ketika seseorang telah menguasai bahasa ibu tanpa mengetahui bahasa kedua. Begitu juga yang dilakukan Hamzah Fansuri dalam menggunakan kata Arab, tidak semua kata Arab yang digunakan benar. Ada beberapa kesalahan yang sebenarnya ia menghendaki makna yang dituju namun memakai kata Arab yang kurang sesuai. Misalnya, kata markūbmu makna yang dikehendaki sebenarnya adalah "kendaraanmu", namun kata itu memiliki makna "sepatu boot (sepatu tinggi)". ${ }^{22}$ Harusnya Hamzah Fansuri memakai kata

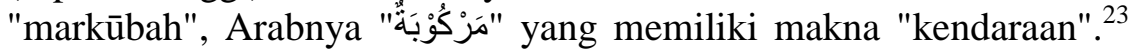
Fenomena ini selaras yang dikemukakan Abdul Aziz al-Ashili, bahwa interferensi bahasa yaitu pemindahan seorang penutur pada tatabahasa bahasa ibunya dan struktur bahasa ibunya kepada bahasa kedua dalam tuturan lisan dan tulisan. ${ }^{24}$

Penggunaan kosakata Arab oleh Hamzah Fansuri di dalam syair Rubā'inya menandakan bahwa ia seorang multilingual. Bahasa Melayu telah memberikan pengaruh pada penggunaan kata Arab, khususnya pada bentuk imbuhan bahasa Melayu yang masuk pada kata Arab. Inilah yang dimaksud Huagen, ia menyebutkan bentuk lain yang mungkin ditimbulkan oleh kontak bahasa ialah terjadinya saling menutupi bagiannya diantara bahasa-bahasa itu, yaitu penerapan dua bahasa secara serempak kepada satu bahasa.

Di sisi lain, bahasa yang ia gunakan selain bahasa ibunya kurang menguasai secara sempurna, akibatnya Hamzah Fansuri sebagai penutur multilingual dan telah mengalami kontak bahasa menimbulkan dampak negatif dari tataran linguistik, yaitu subsistem

22 Ahmad Warson Munawir, Kamus al-Munawwir Arab-Indonesia Terlengkap, (Surabaya: Pustaka Progressif, 1997), h. 526.

${ }^{23}$ Ibid., h. 525.

24 'Abdul Aziz Ibrahim al-'Asyīī̄, Tarāiqu ta'limu al-'lughah al'Arabiyyah lil nāțiqīn bi lughāt 'ukhrāa, (Riyad: Maktabah al-Mulk Fahda alWațaniyyah, 2002), h. 248. 
fonologi, sintaksis, terlebih pada tataran subsistem morfologi. Namun ditataran subsitem leksikal atau kosakata, interferensi memberikan dampak positif. Misalnya, kata teradat memiliki arti telah menjadi kebiasaan. ${ }^{25}$

\section{b. Hamzah Fansuri Seorang Sufi}

Hamzah Fansuri selain terkenal seorang penyair, ia juga pelaku tasawuf atau seorang sufi. Bagaimana cara membuktikan ia seorang sufi?, dapat melihat dalam bait puisi Rubā'i bahwasanya Hamzah Fansuri sangat sering sekali menggunakan nama-nama tokoh sufi yang menggunakan istilah-istilah Arab dan dijadikan petikan dalam bait puisinya, antara lain Bayazid al-Bisthami, Mansur al-Hallaj, Junaid al-Baghdadi, Imam al-Ghazali, Ibn 'Arabi, Fariduddin al'Aththar, jalaluddin Rumi, Fakhrudin 'Iraqi.

Bentuk pengalaman rohani Hamzah Fansuri sebagai seorang sufi tertuang dalam bait-bait puisi Rubā'inya, dan terbilang cukup banyak mengandung istilah-istilah Arab yang digunakan oleh tokoh sufi sebelumnya. misalnya, kata ma'rifat, fana, mahbūb, dan lainlain. Selain itu penggunaan nama diri dan takhallus ${ }^{2 \dot{6}}$, yaitu julukan yang biasanya didasarkan pada nama tempat kelahiran penyair atau kota tempat ia dilahirkan, seperti kata fansüri. Hal tersebut di atas menguatkan Hamzah Fansuri sebagai tokoh sufi.

\section{c. Pengaruh Islamisasi di Nusantara}

Sejarah awal sebelum Islam masuk di tanah Nusantara adalah masyarakat Sumatra, khususnya masih menganut agama Hindu dan Buddha. Para penganut agama Hindu dan Buddha tidak berasal dari kalangan masyarakat bawah, namun dari raja-raja yang mempunyai kedudukan tertinggi pada saat itu. Persoalan yang muncul, ketika para raja yang mempunyai kekuasaan, mereka menyuruh masyarakat untuk beragama dan menyakini apa yang dibawa oleh raja. Kepercayaan yang di bawa oleh raja menyebar ke seluruh rakyatnya,

${ }^{25}$ Lihat di http://dictionary.bhanot.net/ Kamus Bahasa Melayu-Inggeris diakses 5 April 2017.

${ }^{26}$ Takhallus nama julukan yang lazim digunakan para penulis Arab dan Persia, khususnya penulis sufi dan khususnya pula sejak abad ke-13. Penyair Persia biasa mencantumkan nama diri dan takhallus-nya apabila menulis ghazal, yaitu pada bait terakhir setiap untaian ghazal-nya. Kata takhallus berasal dari bahasa Arab, dari akar kata kh $l$ (خل), yang artinya "menjadi bebas". Berdasarkan hal ini takhallus digunakan sebagai pembebasan diri. Lihat Henry Blochman, The Prosody of the Persian According to Saifi, Jami and Other Writers (St. Leonard-Amsterdam: Ad Orienttem Ltd and Philo Press, 1970), h. 91. 
buktinya ketika para raja mengadakan suatu ritual untuk memuji dewa-dewa, masyarakat sekitar ikut andil melakukannya.

Hal di atas tidak cukup lama, karena pada abad ke 13, agama Islam mulai menyebar di kawasan Nusantara. Lebih-lebih para pendakwah agama Islam mulai memperkenalkan ajaran Islam kepada para raja. Akhirnya terjadi proses Islamisasi yang dianggap resmi. Karena di dalamnya terdapat kekuatan politik dan dan pemerintahan Islam. Ketika para tokoh pimpinan di suatu tempat, terutama sultan (raja), keluarga, dan orang-orang terkemukanya memeluk Islam, maka akan berakibat sebagian besar rakyatnya juga ikut memeluk Islam, meskipun sebagian di antara mereka telah terlebih dahulu memeluk agama tersebut. ${ }^{27}$

Dampak Islamisasi pada saat itu terjadi secara masif. Para ulama', syaikh, dan pendakwah menyebarkan agama Islam secara gencar. Mereka melakukan dakwah untuk mengajak masyarakat memeluk agama Islam. Ada banyak cara yang dilakukan oleh para ulama' untuk menyebarkan agama Islam, baik lewat lisan, teladan/ tingkah laku dan tulisan. Penyebaran agama Islam yang dilakukan dengan lisan, teladan/ tingkah laku menjadi metode yang biasa dilakukan. Sedangkan secara tulisan, para ulama' jarang melakukannya, karena selain mempunyai ide/ gagasan tema yang akan ditulis, juga membutuhkan skill tentang kepenulisan. Inilah yang jarang dimiliki oleh sebagian para pendakwah Islam, tentang bagaimana menyebarkan agama Islam lewat tulisan. Minoritas pendakwah melalui karya tulis inilah Hamzah Fansuri tampil sebagai penulis produktif pada masanya.

Hamzah Fansuri selain dikenal sebagai seorang tokoh yang disegani pada masanya, ia juga seorang penulis yang produktif. Terbukti banyak karya dihasilkan dari tangannya, tidak kurang dari 5 karya berbentuk prosa dan puisi. Metode dakwah yang dipakai oleh Hamzah Fansuri di dalam karyanya adalah menyisipkan kata-kata Arab, diantaranya: ayat al-Qur'an, ucapan nabi Muhammad Saw (alHadis), hadis Qudsi (subtansi isi dari Allah redaksi dari nabi Muhammad Saw), ungkapan-ungkapan sahabat Nabi, para sufi, dan kosakata Arab lainnya. itu semua secara tidak langsung mengajak masyarakat untuk lebih kenal dengan agama Islam, karena kitab pedoman umat Islam berbahasa Arab, begitu juga hadis nabi

${ }^{27}$ Sangidu, Wahdatul Wujud: Polemik Pemikiran Sufistik antara Hamzah Fansuri dan Syamsuddin as-Sumatrani dengan Nuruddin ar-Raniri. (Yogyakarta: Gama Media, 2003), h. 23. 
Muhammad Saw, dan ungkapan-ungkapan Arab lainnya. Inilah dampak yang disebabkan gerakan Islamisasi yang pesat pada masa itu.

Telah disebutkan bahwa para sarjana Barat, bahwa Islam datang di Nusantara adalah para pedagang Muslim yang menyebarkan agama Islam sembari melakukan perdagangan di wilayah Nusantara. Ada yang mengatakan pula, para pedagang muslim melakukan pernikahan dengan wanita setempat dan membentuk keluarga muslim, yang pada gilirannya memainkan cukup andil dalam penyebaran agama Islam. Mengenai Islam di bawa langsung dari negara China atau Gujarat, India, al-Attas berperdapat bahwa Islam langsung di bawa dari Arab. ${ }^{28}$

\section{d. Puisi Sebagai Budaya Kesusastraan Awal Islam di Nusantara}

Faktor non linguistik selanjutnya ialah puisi sebagai budaya kesusastraan awal Islam di Nusantara. Awalnya kedudukan puisi dalam pandangan Islam kurang disambut baik oleh ulama-ulama dahulu. Namun tak sedikit pula, beberapa penyair mempunyai pengaruh dan dapat mengispirasi banyak orang. Kita mengenal karyakarya Rumi dan Iqbal, dan Hamzah Fansuri pastinya telah memberikan corak kesusastraan awal Islam. Selain itu, di luar masyarakat karya itu lahir, suatu karya sastra khususnya bernuansa Islami telah memberikan sumbangan bagi peradaban dunia dalam mengembangkan ilmu pengetahuan dan penulisan kreatif.

Braginsky, menyatakan "Yang berhasil membentuk jantung kebudayaan Melayu ialah persuratan, kesusastraan dan kalam para sastrawan, dan ulama sufi". ${ }^{29}$ Pernyataan tersebut menguatkan bahwasannya puisi merupakan kebudayaan awal Islam di Nusantara. Metode corak dakwah pada abad ke-16 dan 17 di Nusantara lebih mengutamakan pada proses pengukuhan dan pengembangan Islam melalui islamisasi bahasa, kesusastraan, dan kebudayaan. ${ }^{30}$

Dari aspek lahir dan batinnya, puisi menempati kedudukan strategis di dalam kebudayaan masyarakat. Budaya awal Islam di Melayu harus mengawalinya dengan menggali sejarah Islam itu

28 Azumardi Azra, Jaringan Ulama Timur Tengah dan Kepulauan Nusantara Abad XVII dan XVIII: Melacak akar-akar pembaharuan pemikiran Islam di Indonesia, (Bandung: Mizan, 1994), h. 29.

${ }^{29}$ Abdul Hadi, W.M., Kembali ke Akar Kembali ke Sumber Esai-esai Sastra Profetik dan Sufistik, (Jakarta: Pustaka Firdaus, 1999), h. 65.

${ }^{30}$ Ibid. 
sendiri. Karena sejarah Islam erat kaitannya dengan kebudayaan Islam itu sendiri, dan kebudayaan Islam itu bersifat kebudayaan sastera. Dari hal itu, maka ciri-ciri kesan Islam pada sejarah suatu bangsa harus dicari bukan pada perkara-perkara atau sesuatu yang lahir dan mudah tampak oleh mata kepala tetapi lebih pada perkaraperkara atau sesuatu yang terselip tersembunyi dari pandangan biasa, seperti pemikiran suatu bangsa yang biasa terkandung dalam bahasa. ${ }^{31}$

Dari sumber-sumber kesusasteraan Melayu yang berunsurkan intelektualisme dan rasionalisme Islam pada abad ke-16 dan ke-17, terbayang pada pandangan akal tentang gambaran perubahan mendalam yang telah berlaku terhadap jiwa masyarakat Melayu. Artinya, puisi pada masa itu tidak hanya menyuarakan tentang halihwal dan pernak-pernik kehidupan masa itu, namun lebih dari itu, aspek religius yang dibangun puisi lebih terhadap dunia dalam (tasawuf). Hal ini sesuai dengan pernyataan al-Attas yang menggambarkan kebudayaan awal Islam di Melayu. Yaitu bagai kecapi yang belum pernah terpetik melagukan irama filsafat murni, kini berlanggam diiringi seruling tasawuf menyuarakan bisikan pikiran dan perasaan halus-luhur. ${ }^{32}$

Selain istilah Arab yang sangat banyak ditemukan dalam karangan bahasa Melayu, juga ditemukan bahasa Parsi. Hal ini dikarenakan masa awal Islam, para pendakwah sekaligus pedagang ada yang berasal dari Persia. Kembali pada pembahasan, bahwasanya bahasa Melayu diibaratkan sebagai sungai itu menjadi laut yang lambat-laun sampai juga arusnya ke pantai pemikiran dunia antarbangsa. Nasib bahasa Melayu yang terpengaruh Islam itu sangat mesra berpadu sehingga tidak dapat dilupakan sejarah bahwa kedua faktor ini di saat pertama telah menanamkan kesadaran paham kebangsaan ke dalam jiwa masyarakat Melayu-Indonesia, dan sekarang menjadikan bahasa Melayu sebagai bahasa kebangsaan bangsa Indonesia. ${ }^{33}$

\section{e. Berkembangnya Tulisan Jawi (Melayu-Arab)}

Tulisan Jawi merupakan awal dari kepenulisan dalam bahasa Melayu, bentuk tulisan Jawi berasal dari tulisan Arab namun isinya berasal dari bahasa Melayu. Istilah-istilah yang berasal dari bahasa

${ }^{31}$ Syed Muhammad Naguib al-Attas, Islam dalam Sejarah Kebudayaan Melayu, (Bandung: Mizan, 1990), h. 37.

\footnotetext{
${ }^{32}$ Ibid., h. 37.

${ }^{33}$ Ibid., h. 42-43.
} 
Arab langsung ditulis sebagaimana tulisan Arab. Mengenai tulisan Melayu-Arab itu sendiri tidak terlepas dari berkembangnya dunia tulis menulis dalam kebudayaan Melayu. Sebelumnya perlu diketahui bahwa tulisan Jawi pada masa itu mempunyai andil cukup besar bagi peradaban dunia.

Bahasa Melayu yang tadinya merupakan bahasa pasaran terbatas itu telah mengalami suatu perubahan besar, suatu revolusi. Selain diperkaya perbendaharaan katanya dengan istilah-istilah dan perkataan-perkataan Arab dan Parsi, bahasa Melayu juga dijadikan bahasa pengantar utama Islam di seluruh Kepulauan MelayuIndonesia, sehingga selambat-lambatnya pada abad ke-16 berjaya mencapai peringkat bahasa sastra dan agama yang luhur. Dan sanggup menggulingkan kedaulatan bahasa Jawa dalam berbagai bidang dan tersebar luasnya bahasa Melayu itu merupakan akibat penggunaannya oleh Islam sehingga ini dapat menjadi bahasa resmi lebih dari 100 juta manusia di Asia Tenggara. Dengan ini pula bahasa Melayu-Indonesia itu harus dianggap sebagai bahasa Islam, dan mungkin merupakan yang kedua terbesar dalam dunia Islam. ${ }^{34}$

Pada abad permulaan ke-17 banyak manuskrip Jawi tertua dikumpulkan di Aceh. Karya teologi dianggap sebagai karya terakhir abad ke 16 yang bersumber dari masa yang sama sebagai syair versi mistik yang kompleks dari Hamzah Fansuri dan dipercaya dilahirkan sebelum tahun 1590 di Barus, barat laut Sumatra. Prosa dan puisi karya Hamzah Fansuri (yang kemudian hanya salinannya saja yang masih hidup) menyuarakan interpretasi mistik Islam, yang memimpin seluruh penyair dan ahli agama aliran Sumatra dan juga intelektual abad ke-17 serta konflik agama dengan sarjana Muslim yang lebih ortodoks, misalnya sarjana agama bangsa Gujarat, Nuruddin alRaniri, ia juga merupakan ahli agama yang menyebarkan sejumlah karya bahasa Melayu yang mempunyai dampak penting bagi penyebaran agama Islam dan bahasa Melayu. ${ }^{35}$

Pengaruh tulisan Jawi ini, memberikan dampak yang luar biasa untuk berkembangnya tulisan Arab di kepulauan Nusantara. Hal ini menandakan bahasa Arab telah menjadi bahasa komunikasi, bahasa kesusasteraan, dan bahasa tulis di kalangan masyarakat lokal. Bahasa Arab telah diterima suka cita oleh masyarakat Melayu, dan hingga

${ }^{34}$ Syed Muhammad Naguib al-Attas, Islam dalam Sejarah ..., h. 62-63.

${ }^{35}$ James T. Collins, Bahasa Melayu Bahasa Dunia, Sejarah Singkat, Cet. II, (Jakarta: Yayasan Pustaka Obor Indonesia, 2011), h.24-27. 
sekarang banyak istilah-istilah Arab diserap ke dalam bahasa Melayu untuk dijadikan warga bahasanya.

Dari kedua faktor utama di atas, yaitu faktor linguistik dan non linguistik dapat disimpulkan bahwa Hamzah Fansuri melakukan interferensi bahasa secara sistemik, artinya Hamzah Fansuri melakukan pungutan bahasa Arab dalam jumlah yang cukup besar di dalam puisi Rubā'inya. Hal inilah yang menjadikan Hamzah Fansuri dikatakan sebagai perilaku individu dalam berbahasa di tengah masyarakat. Ia menginginkan bahasa Arab lebih dikenal di lingkungan Hamzah Fansuri hidup. Secara tidak langsung Hamzah Fansuri mengajak masyarakat lain untuk lebih mengenal bahasa Arab, bahasa al-Qur'an, pedoman umat Islam, dan mensyiarkan agama Islam.

\section{E. Kesimpulan}

Bentuk-bentuk interferensi yang terjadi pada puisi Rubā'i karya Hamzah Fansuri, diantaranya: terjadi afiksasi imbuhan morfem bahasa Melayu ke dalam morfem bahasa Arab, baik berbentuk nomina dan verba. Adapun proses pembentukan kata melalui proses afiksasi (proses penambahan imbuhan pada kata dasar), diantaranya: prefik (awalan), sufiks (akhiran), konfiks (awalan dan akhiran), dan kata gandaan (majemuk). Terdapat 241 kata berafiks di dalam 192 bait, berikut uraiannya: (1) Prefiks 48 kata, terdiri dari prefiks ber20, prefiks ter- 2 kata, prefiks kau- 25 kata, prefiks ke- 1 kata. (2) Sufiks 184 kata, terdiri dari sufiks sufiks -lah 2 kata, sufiks - pun 2 kata, sufiks -kau 1 kata, sufiks -i 6 kata, sufiks -nya 121 kata. (3) Konfiks 9 kata, terdiri dari konfiks di- kan 4 kata, konfiks kau- -kan 1 kata, konfiks me--kan 4 kata, dan kata gandaan/ majemuk 2 kata.

Sebab-sebab interferensi yang dilakukan oleh Hamzah Fansuri terdapat dua faktor utama, yaitu faktor linguistik (kebahasaan) dan faktor non linguistik (non kebahasaan). Dari faktor linguistik (kebahasaan) antara lain: tidak ada padanan kata dalam bahasa Melayu, terbawanya bahasa ibu, kosakata Arab luas makna padat kata. Dari faktor non linguistik (non kebahasaan) antara lain: Hamzah Fansuri seorang multilingual, Hamzah Fansuri seorang sufi, pengaruh islamisasi di Nusantara, puisi sebagai budaya kesusastraan awal Islam di Nusantara, berkembangnya tulisan Jawi (Melayu-Arab).

Penggunaan bahasa oleh Hamzah Fansuri di dalam puisi Rubā' $i$ merupakan sebuah bentuk perilaku individu berbahasa di dalam 
Ihsanudin dan Aimmatul Muslimah

masyarakat. Ia juga telah melakukan interferensi bahasa secara sistemik, yaitu memungut bahasa Arab secara terus menerus. [] 


\section{DAFTAR PUSTAKA}

al-Attas, Syed Muhammad Naguib, Islam dalam Sejarah Kebudayaan Melayu, Bandung: Mizan, 1990.

al-"Asȳili, "Abdul Aziz Ibrahim, Tarāiqu ta'limu al-'lughah al'Arabiyyah lil nāțiqīn bi lughāt ukhrā, Riyad: Maktabah alMulk fahda al-Wațaniyyah, 2002.

Azra, Azumardi, Jaringan Ulama Timur Tengah dan Kepulauan Nusantara Abad XVII dan XVIII: Melacak akar-akar pembaharuan pemikiran Islam di Indonesia, Bandung: Mizan, 1994.

Blochman, Henry, The Prosody of the Persian According to Saifi, Jami and Other Writers (St. Leonard-Amsterdam: Ad Orienttem Ltd and Philo Press, 1970)

Chaer, Abdul dan Leonie Agustina, Sosiolinguistik Perkenalan Awal, Jakarta: Rineka Cipta, 2001.

Claude, Guillot dan Ludvik Kalus. Batu Nisan Hamzah Fansuri, terj. Rita Parasman, Jakarta: Ecole Francaise d'Extreme-Orient dan Departemen Kebudayaan dan Pariwisata, 2007.

Collins, James T., Bahasa Melayu Bahasa Dunia, Sejarah Singkat, Cet. II, Jakarta: Yayasan Pustaka Obor Indonesia, 2011.

Drewes, G.W.J dan L.F. Brake. The Poems of Hamzah Fansuri, U.S.A: Foris Publications Holland, 1986.

Ensiklopedi Indonesia, Jakarta: 1980.

Hadi, Abdul, W.M., Tasawuf yang Tertindas: Kajian Hermeneutik terhadap Karya-karya Hamzah Fansuri, Jakarta: Paramadina, 2001.

, Kembali ke Akar Kembali ke Sumber Esai-esai Sastra Profetik dan Sufistik, Jakarta: Pustaka Firdaus, 1999.

Kurdi, Muliadi, Hamzah Fansuri: Ulama Aceh Terkenal Dalam Kealiman dan Kesufian. Aceh: Lembaga Naskah Aceh "NASA", 2013.

Munawir, Ahmad Warson, Kamus al-Munawwir Arab-Indonesia Terlengkap, Surabaya: Pustaka Progressif, 1997.

Nababan. P.W.J. Sosiolingustik, Jakarta: Gramedia, 1984.

Ohoiwutun, Paul, Sosiolinguistik: Memahami Bahasa dalam Konteks Masyarakat dan Kebudayaan, Jakarta: Visipro, 2002.

Pranowo, Analisis Pengajaran Bahasa Untuk Mahasiswa Jurusan Bahasa dan Guru Bahasa, Yogyakarta: Gadjah Mada University Press, 1996. 
Ihsanudin dan Aimmatul Muslimah

Sangidu, Wahdatul Wujud: Polemik Pemikiran Sufistik antara Hamzah Fansuri dan Syamsuddin as-Sumatrani dengan Nuruddin ar-Raniri. Yogyakarta: Gama Media, 2003.

Thomason, Sarah G, Language Contact, Edinburgh: Edinburgh University Press Ltd, 2001.

http://dictionary.bhanot.net/ Kamus Bahasa Melayu-Inggeris diakses 5 April 2017. 